\title{
FACTORS AFFECTING ECONOMIC GROWTH: EMPIRICAL EVIDENCE FROM DEVELOPING COUNTRIES
}

\section{Marta Zieba $^{1}$, Thi-Kieu-Trang Dong ${ }^{2}$, Rahab Njeri Mbugua ${ }^{3}$}

\begin{abstract}
The question around factors affecting economic growth in developing nations is widely debated as it influences the policies to promote economic welfare. This paper, therefore, determines the factors influencing economic growth in developing countries. By estimating a fixed-effect model with a panel dataset for 62 developing countries from 2010 to 2018, the study found that government spending and natural resource rents have a favourable impact on per capita GDP growth. In contrast, rising labour force participation and inflation stifle economic growth in these countries.
\end{abstract}

Keywords: developing countries, economic growth, Fixed Effect model, and panel data

\footnotetext{
${ }^{1}$ Lecturer, Kemmy Business School, University of Limerick

${ }^{2}$ Student, Kemmy Business School, University of Limerick

${ }^{3}$ Student, Kemmy Business School, University of Limerick
} 


\section{Introduction}

Poverty, high population growth, and outdated technologies have been the main challenges facing developing countries with heavily reliant economies on government activities (Upreti, 2015). On the other hand, neoclassical economist Robert Solow established labour, capital, and technology as the key factors influencing economic growth. Keynesians further developed the theory by introducing government expenditure as a critical driver to economic growth. Notably, developing countries still lag in economic growth despite being abundantly endowed with natural resources and high populations (Barbier 2012). Therefore, understanding variables that influence developing countries' economic growth is critical for designing suitable economic policies for any government or institution. Researchers have explored this area using a variety of tools and approaches. These studies, however, did not employ recent datasets, which are consistent with the dynamics of economic growth.

This study examines factors influencing economic growth in developing countries using an updated dataset from 2010 to 2018 based on World Bank data. Section 2 presents an empirical literature review highlighting some critical traits of developing countries. Section 3 sets the empirical method with which our model will be tested. Section 4 presents the dataset and our summary statistics, while section 5 and 6 discusses the empirical results and the arguments on the validity of the findings. Finally, section 7 presents the conclusions, policy implications, and study's limitations.

\section{Literature Review}

This section examines previous studies on economic growth factors, focusing on the labour force, natural resources, public expenditure, and inflation.

\subsection{Labour force}

Banda (2015) established a consistent positive relationship between the labour force and output per worker, a measure of economic productivity in Mauritius and South Africa from 2002 to 2012. However, a hindrance to optimum productivity was a mismatch in specialized skills 
produced from the education system to the labour market requirements. As the population grew in the developing nations, the labour force also increased due to the high absorption rate in 1960-1985 hence the positive economic growth (Bloom and Freeman 1986).

\subsection{Public Expenditure}

According to the Keynesian theory of economic growth, government expenditure positively impacts economic growth (Parui 2021). Public expenditure spurs domestic consumption, exports, and employment through the multiplier effect, thus generating more national income. Barro's (1996) research established that current and development expenditure had a positive relationship in 100 countries in their sample for 1960-1995. Thus, he concluded that governments should spend more to boost economic growth. Additionally, Kimaro et al. (2017) also established a positive impact of public expenditure on economic growth in 25 Subsaharan Africa countries using the Gaussian Mixture model. However, other researches demonstrated the negative effect of government expenditure on economic growth. According to Devarajan et al. (1996), excessive government expenditure was unproductive in the 25 developing countries based on their research.

\subsection{Natural Resources}

The abundance of natural resources has been theoretically associated with increased economic development as they lead to more exports and generate natural resource rent (Auty 2003). However, recent studies indicate that developing nations do not benefit economically from their abundant natural capital stock. Barbier (2012) established stagnant growth from low and middle-income developing countries with significant natural resources stocks. His panel data analysis on 867 low-income countries showed increased agricultural land expansion in a lower per capita income level. This result confirmed the inverse relationship between natural resources and income per capita growth on mineral-driven economies study by Wright and Czelusta (2011). They concluded that the abundance of natural resources was more of a curse than a blessing to a developing country.

\subsection{Inflation}

The subject of inflation and economic growth in developing countries has been of interest to many policymakers and researchers. Some economists argue that some inflation is necessary for economic growth, while others consider it detrimental (Omotunde 1984). Andrés and Hernando (2014) established a significantly negative relationship between economic growth 
and inflation in OECD countries. Their research showed that inflation negatively affected the propensity to invest and reduced the efficiency of inputs used in production. On the other hand, Ndoricimpa (2017) estimated an inflation threshold of 9\% for low-income countries and $6.5 \%$ for middle-income countries to positively impact growth. Above the threshold, it was considered detrimental to these countries' economic development.

Given the various studies on factors influencing economic growth in developing countries, it is worthwhile to estimate the factors currently affecting developing nations for better policy development.

\section{Empirical Approach}

Following Upreti (2015), we estimated the OLS model as follows:

GROWTH $_{i t}=\beta_{o}+\beta_{1} L F_{i t}+\beta_{2} E_{i t}+\beta_{3} R E S O U R C E_{i t}+\beta_{4} I N F L A+\mu_{i}$

Where:

$i$ is the Country

$t$ is the year $2010, \ldots, 2018$

$\mu_{i}$ is the error term

The dependent variable for the model is economic growth as GDP per capita (GROWTH) and is measured as a percentage growth rate. GDP per capita is a measure of a country's economic production per person, computed by dividing a country's GDP by its population.

The first control variable is the labour force growth rate (LF) which we predicted to have a positive outcome. The labour force growth rate is the percentage change in labour force participation, which is the proportion of the population aged 15 and older who is economically active: all people who supply labour to produce goods and services, from the previous year to the next. Increasing the size of the labour force generates additional human resources, which contributes positively to economic growth. With significant and cheap labour resources, developing countries will attract investment, ultimately encouraging economic expansion (see Abounoori and Nademi (2010) and Akpan and Abang (2013)).

The second explanatory variable is general government final consumption expenditure (EXP), where we predicted a positive coefficient. General government final consumption expenditure includes all government current expenditures for purchases of goods and services. According to Keynes (1937), the government needs to take adequate measures to increase demand and stimulate production and consumption. Besides, the government can use the budget to carry 
out orders, provide financial subsidies, and ensure stable profits for the private sector (Alshahrani and Alsadiq 2014). Furthermore, the government could provide public goods and services essential for socio-economic development (Hong and Ahmed 2009).

The third independent variable is the total natural resource rents (RESOURCE) measured as a percentage of GDP. Total natural resources rents are the sum of oil rents, natural gas rents, coal rents (hard and soft), mineral rents, and forest rents. Previous studies showed that resource export could have a good influence, assisting countries in developing (see Ben-Salha et al. (2018)), or a negative impact, owing to the Dutch Disease (see Abdulahi (2019)). The predicted sign of the coefficient, therefore, is ambiguous.

Finally, the fourth variable is the consumer price inflation rate (INFLA). As measured by the consumer price index, inflation represents the annual percentage change in the cost to the average consumer of acquiring a basket of goods and services that may be set or altered at predetermined intervals, such as annually. For several decades, research conducted on the relationship between inflation and economic growth in developing countries has agreed that continuously rising inflation is harmful to economic development and growth (Boyd et al. (1996) and Azariadis and Smith (1996)). However, some scholars have attempted to demonstrate that, to some extent, inflation could be beneficial to growth in developing countries (see Omotunde (1984) and Tobin (1972)). Similar to natural resource rent, the coefficient's predicted sign of INFLA is vague.

Table 1 below presents details of variables, including their units, sources and predicted effects.

Table 1. Description of the variables, their units, their predicted effects on economic growth and their sources

\begin{tabular}{|l|l|l|l|l|}
\hline \hline Variable name & Description & Unit & Source & $\begin{array}{l}\text { Predicted } \\
\text { effect }\end{array}$ \\
\hline GDPGROWTH & GDP per capita growth & $\%$ & World Bank & DV \\
\hline LF & Labour force growth rate & $\%$ & World Bank & + \\
\hline EXP & $\begin{array}{l}\text { General government final } \\
\text { consumption expenditure }\end{array}$ & $\%$ GDP & World Bank & + \\
\hline RESOURCE & Total natural resource rents & $\%$ GDP & World Bank & $+/-$ \\
\hline INFL & Inflation consumer price & $\%$ & World Bank & $+/-$ \\
\hline \hline
\end{tabular}

\section{Data}

The panel data used in this research was sourced from The World Bank (2020) for 62 developing countries and included the World Bank's list of low-income and lower-middleincome economies (See Table 1 - list of countries in appendix). The timeframe 2010-2018 was 
selected to avoid the impacts of global economic slumps. 2010 is considered the global economy's first return to "normal" after the 2007 financial crisis (Rich 2013). Furthermore, the Covid-19 pandemic has had no effects on the global economy before 2018.

Table 2 below represents the summary statistics of the data for the 62 countries used in the study

Table 2. Descriptive statistics for 62 developing countries

\begin{tabular}{|l|l|l|l|l|l|}
\hline \hline Variable & Obs & Mean & Std. dev. & Min & Max \\
\hline GDP growth & 555 & 2.321045 & 4.421558 & -47.59 & 18.07 \\
\hline Labor force growth rate & 558 & 0.022043 & 0.016567 & -0.1 & 0.1 \\
\hline Expenditure & 557 & 26.44575 & 9.200079 & 9.49 & 61.71 \\
\hline Inflation & 554 & 7.187852 & 18.99172 & -2.81 & 380 \\
\hline Natural Resource Rent & 555 & 8.38236 & 8.505355 & 0.07 & 57.2 \\
\hline \hline
\end{tabular}

Source: Own calculations

This dataset was imperfect as there are some missing observations in some variables. The countries GDP growth has a significant disparity indicated by the standard error while the range of GDP growth rate is $-47.59 \%$ (South Sudan) and $18.07 \%$ (Zimbabwe) and an average growth rate of $2.32 \%$. The positive mean is an indication that the countries' GDP is growing. The labour force growth rate ranges between $-0.1 \%$ and $0.1 \%$, with a mean of $0.022 \%$, which is relatively low. This result could be because these countries' labour force growth rate is already high.

Interestingly, government expenditure ranges from 9.49\% GDP (Nigeria in 2016) and $61.71 \%$ GDP (Republic of Congo in 2014), with an average of $26.44 \%$ GDP. The government spending is relatively close to the world government expenditure, which is $27.89 \%$ (World Bank 2021a). The countries depicted significant disparity in inflation as indicated by the standard error with the rate ranging between $-2.81 \%$ (Burundi in 2018) and 380\% (South Sudan in 2013) and an average of $7.18 \% .380 \%$ indicates the hyperinflation rate experienced in South Sudan since 2013 during the fight for independence and is an outlier in the dataset. Notably, the average inflation rate is still relatively high compared to the developed nations, whose inflation was $1.85 \%$ for European Union countries and $1.85 \%$ for the USA in 2018 (World Bank 2021b). Finally, the natural resource rent has a mean of $8.5 \%$, with the highest rate of $57.2 \%$ (South Sudan in 2011) and the lowest rate of $0.07 \%$ (Sri Lanka in 2018). This implies that developing countries are using natural resources quite efficiently when compared with this value for developed countries in the period 2010-2018 of 1.64\% (World Bank 2021c). 


\section{Empirical Results}

The model is initially estimated using the Pooled OLS model with no provision for countryspecific differences (fixed-effects). However, under the null hypothesis $\left(\mathrm{H}_{0}\right)$, the F-statistics that the country-specific effects (individual intercepts) are jointly zero is larger than the critical value at the $1 \%$ level. Thus, we rejected $\mathrm{H}_{0}$ and applied the fixed effects model (see Table 3 below for details).

We then tested the suitability of the fixed effects (FE) model and compared it with the randomeffects (RE) model by using the Hausman test (Gujarati 2015). With a significance level of 5\% and p-value of $0.000<0.05$, we accept the null hypothesis- $\mathrm{H}_{0}$, indicating that the FE is more appropriate than the RE (see Table 6 in the appendix for details). The advantage of the fixed effects (FE) model is its ability to control variables whose characteristics are constant over time. Various studies have used the FE model, including Guseh (1997) and Ram (1986). These studies showed that the FE model effectively assesses the impact of the exploratory variables on economic growth.

Our FE model does not have multicollinearity and autocorrelation at 5\% (see Tables 2 and 4 in the appendix for details). However, we found that the model has heteroskedasticity by applying the Modified Wald test (Baum 2000). The test result is shown in Table 5 in the appendix. Therefore, the robust standard errors were used in the FE model to adjust for the heteroscedastic variance of the error term, and the final results are presented in Table $3 .{ }^{4}$ Finally, by adopting the Ramsey Reset test (Table 6 in the Appendix) using the resetxt command in Stata, developed by Shehata and Mickaiel (2015), we concluded that at a 5\% significance level, the model was correctly specified. This result means that the independent variables can describe the variations in the dependent variable.

Table 3. FE model with the robust standard errors

\begin{tabular}{lcccc}
\hline \hline & $(1)$ & $(2)$ & $(3)$ & $(4)$ \\
\multicolumn{1}{c}{ Dependent variables } & Coefficient & Robust Std. Error & $\begin{array}{c}(3) \\
\text { t-value }\end{array}$ & p-value \\
\hline Labour force growth rate & $-27.259^{* *}$ & $(0.039)$ & -2.07 & 0.039 \\
Government expenditure & $0.084^{*}$ & $(0.055)$ & 1.92 & 0.055 \\
Inflation & $-0.237^{* *}$ & $(0.000)$ & -6.51 & 0.000 \\
Natural resource rents & $0.241^{* * *}$ & $(0.000)$ & 5.46 & 0.000 \\
Constant & 0.148 & $(0.911)$ & 0.11 & 0.911 \\
\hline Observations & 550 & Number of countries & 62
\end{tabular}

\footnotetext{
${ }^{4}$ The FE model with the OLS standard errors which is not adjusted for heteroscedasticity, provided very similar results to those presented in Table 3 and they are presented in Appendix in Table 8.
} 


\begin{tabular}{lcl}
$\begin{array}{l}\mathrm{F} \text { test } \\
\chi 2 \text { Hausman test }\end{array}$ & $\mathrm{F}(61,484)=3.55$ & Prob $>\mathrm{F}=0.0000$ \\
chi2 $(4)=43.81$ & Prob $>$ chi $2=0.0000$ \\
\hline \hline $\mathrm{p}<0.05 ; * * \mathrm{p}<0.01 ; * * * \mathrm{p}<0.001$ &
\end{tabular}

The above results show that the regression coefficient of labour force growth rate (lf) is (27.259). This result indicates that a one per cent increase in the labour force growth rate results in a $27.259 \%$ reduction in the GDP per capita growth. The coefficient is statistically significant, precisely at the $5 \%$ level. Besides, the coefficient is quite significant, indicating that the policy implications on the labour market appear to be crucially helpful in boosting economic growth. The government expenditure appears to have a positive effect on the GDP per capita growth. The coefficient is 0.084 , indicating that for every $1 \%$ increase in government expenditure, the GDP per capita growth will increase by $0.084 \%$. The coefficient is statistically significant at the $10 \%$ level. However, the coefficient is quite small, indicating that while government expenditure affects economic growth, expanding government expenditure does not help thrive the economy.

Inflation appears to have a negative relationship with GDP per capita growth. The coefficient $(-0.237)$ demonstrates that the GDP per capita growth will decrease $0.237 \%$ for every $1 \%$ increase in inflation. This means that governments should reduce inflation at a certain level that could result in high economic growth. The coefficient for inflation is statistically significant at the $1 \%$ level.

The natural resource rents have a positive relationship with the economic growth at the level of $1 \%$. The coefficient is 0.241 , which is a $1 \%$ increase in the natural resource rents leads to a $0.241 \%$ increase in GDP per capita growth.

\section{Discussion}

The descriptive statistics and model estimation show that general government final consumption expenditure and economic growth positively correlate with the significance level at $90 \%$. This finding is consistent with studies of Abounoori and Nademi (2010), Hou and Chen (2013) and Guseh (1997). Public spending in developing countries is essential for economic activities as these countries have economies with many defects and cannot operate effectively on their own. Specifically, the characteristics of public spending in developing countries are mainly infrastructure investment spending, while these countries are still in a state 
of weak infrastructure systems, so the source of government spending is an essential source of economic growth. In addition, government intervention could reduce social inequality while providing an insurance function for private wealth and encouraging private investment.

The study also shows that total natural resource rents and economic growth have a positive relationship and is consistent with the conclusion of Aljarallah (2021) and Ben Salha et al. (2018). In this case, the 62 developing countries appeared not to encounter Dutch Disease. Besides, the directional relationship between GDP growth and total natural resources rents seems consistent with the study of Lyatuu et al. (2021). They indicated that an increase in resource rents leads to a substantial increase in government income in the short term, which can transpose into government spending. Thus, natural resources could help governments finance the environmental and other development-oriented programs needed to improve GDP growth.

The study found that inflation (infla) has a negative impact on GDP growth rates. Findings by De Gregorio (1992), Burdekin et al. (1994), and Iqbal and Nawaz (2009) also concluded the same trend. Indeed, Fischer (1993) argued that inflation distorts resource distribution due to detrimental changes in relative pricing. Changes in the pricing of different items cause comparable prices, distorted consumer decisions, and the market's inability to allocate resources efficiently when inflation is high. Furthermore, inflation diminishes investment, which is the economy's source activity. In the long run, uncertainty about the volatility of inflation is the primary cause of investment reduction.

Notably, the study unexpectedly showed a negative relationship between labour force size growth and GDP growth which is reverse to our prediction but consistent with the findings of Fan (2008). One of the two primary production inputs is labour, and labour accumulation is a source of economic expansion. This reverse outcome could be explained by labour market inefficiency or low labour productivity in emerging countries.

\section{Conclusion}

Research on key drivers to economic growth among developing countries has been of great interest to policymakers, governments, researchers, and investors in the recent past. These factors are vital in highlighting activities occurring in developing nations and aid in devising policies to foster sustainable growth and development in the economy. 
This paper sought to establish factors affecting economic activities in 62 developing countries from 2010 to 2018. Labour force growth and inflation rates harmed economic growth. Although the labour force growth rate was contrary to the prediction, it highlighted inefficiency in the labour market, which implies that the policies in the labour market need to be evaluated. Moreover, governments should devise monetary and fiscal policies that ensure relatively low inflation rates as high inflation rates are detrimental to economic growth. On the other hand, natural resource rent and public expenditures were good boosters of economic growth. Therefore, investments to maximize economic benefits for the endowed countries were critical for their economic development. However, policies to ensure that environmental health was maintained and government expenditure did not result from misappropriation of funds towards these activities are paramount.

However, due to time constraints and data availability, we omitted other essential indices of economic growth, such as education levels and technological advancements. We seek to explore these factors further and build on the labour inefficiency as detected in section 5 . 


\section{References}

Abdulahi, E. (2019) 'Resource rents, economic growth, and the role of institutional quality: A panel threshold analysis $\boldsymbol{\sim}^{\prime}$ ', Resources Policy, 61, 293-303, available: http://dx.doi.org/10.1016/j.resourpol.2019.02.011.

Abounoori, E. and Nademi, Y. (2010) 'Government size threshold and economic growth in Iran', International Journal of Business and Development Studies, 2, 95-108.

Akpan, U. and Abang, D. (2013) 'Does Government Spending Spur Economic Growth? Evidence from Nigeria', Journal of Economics and Sustainable Development, 4, 3652.

Aljarallah, R.A. (2021) 'An assessment of the economic impact of natural resource rents in kingdom of Saudi Arabia', Resources Policy, 72, 102070, available: http://dx.doi.org/https://doi.org/10.1016/j.resourpol.2021.102070.

Alshahrani, S. and Alsadiq, A. (2014) 'Economic Growth and Government Spending in Saudi Arabia: an Empirical Investigation', IMF Working Papers, 14, 1, available: http://dx.doi.org/10.5089/9781484348796.001.

Andrés, J. and Hernando, I. (2014) 'Inflation and economic growth : some evidence for the OECD countries', in.

Auty, R. (2003) 'Natural Resources, Development Models and Sustainable Development', SSRN Electronic Journal, available: http://dx.doi.org/10.2139/ssrn.424082.

Azariadis, C. and Smith, B.D. (1996) 'Private information, money, and growth: Indeterminacy, fluctuations, and the Mundell-Tobin effect', Journal of Economic Growth, 1(3), 309-332, available: http://dx.doi.org/10.1007/BF00141041.

Banda, B. (2015) 'The Impact of Labour Productivity on Economic Growth: The Case of Mauritius and South Africa', Southern African Journal of Policy and Development, 2, 26-41.

Barbier, E.B. (2012) '2002 - The role of natural resources in economic development' in Anderson, K., ed., Australia's Economy in its International Context University of Adelaide Press, 487-516.

Baum, C. (2000) 'XTTEST3: Stata module to compute Modified Wald statistic for groupwise heteroskedasticity'.

Ben-Salha, O., Dachraoui, H. and Sebri, M. (2018) 'Natural resource rents and economic growth in the top resource-abundant countries: A PMG estimation', Resources Policy, 101229, available: http://dx.doi.org/https://doi.org/10.1016/j.resourpol.2018.07.005.

Ben Salha, O., Dachraoui, H. and Sebri, M. (2018) 'Natural resource rents and economic growth in the top resource-abundant countries: A PMG estimation', Resources Policy, (Forthcoming), available: http://dx.doi.org/10.1016/j.resourpol.2018.07.005.

Bloom, D.E. and Freeman, R.B. (1986) 'The Effects of Rapid Population Growth on Labor Supply and Employment in Developing Countries', Population and Development Review, 12(3), 381-414, available: http://dx.doi.org/10.2307/1973216.

Boyd, J.H., Choi, S. and Smith, B. (1996) 'Inflation, financial markets and capital formation', Review, 78(May), 9-35. 
Burdekin, R.C.K., Goodwin, T., Salamun, S. and Willett, T.D. (1994) 'The effects of inflation on economic growth in industrial and developing countries: is there a difference?', Applied Economics Letters, 1(10), 175-177, available: http://dx.doi.org/10.1080/135048594357952.

De Gregorio, J. (1992) 'The effects of inflation on economic growth: Lessons from Latin America', European Economic Review, 36(2), 417-425, available: http://dx.doi.org/https://doi.org/10.1016/0014-2921(92)90098-H.

Devarajan, S., Swaroop, V. and Zou, H.-f. (1996) 'The composition of public expenditure and economic growth', Journal of Monetary Economics, 37(2), 313-344, available: http://dx.doi.org/https://doi.org/10.1016/S0304-3932(96)90039-2.

Fan, S. (2008) 'Public Expenditures, Growth, and Poverty: Lessons from Developing Countries', International Food Policy Research Institute (IFPRI), Issue briefs, 26, available: http://dx.doi.org/10.1355/ae26-2k.

Fischer, S. (1993) 'The role of macroeconomic factors in growth', Journal of Monetary Economics, 32(3), 485-512, available: http://dx.doi.org/https://doi.org/10.1016/03043932(93)90027-D.

Gujarati, D. (2015) 'Panel Data Regression Models' in, 326-343.

Guseh, J.S. (1997) 'Government Size and Economic Growth in Developing Countries: A Political-Economy Framework', Journal of Macroeconomics, 19(1), 175-192, available: http://dx.doi.org/https://doi.org/10.1016/S0164-0704(97)00010-4.

Hong, H. and Ahmed, S. (2009) 'Government Spending on Public Goods: Evidence on Growth and Poverty', Economic and Political Weekly, 44(31), 102-108.

Hou, N. and Chen, B. (2013) 'MILITARY EXPENDITURE AND ECONOMIC GROWTH IN DEVELOPING COUNTRIES: EVIDENCE FROM SYSTEM GMM ESTIMATES', Defence and Peace Economics, 24(3), 183-193, available: http://dx.doi.org/10.1080/10242694.2012.710813.

Iqbal, N. and Nawaz, S. (2009) 'Investment, Inflation and Economic Growth Nexus', The Pakistan Development Review, 48(4), 863-874.

Keynes, J.M. (1937) 'The General Theory of Employment', The Quarterly Journal of Economics, 51(2), 209-223, available: http://dx.doi.org/10.2307/1882087.

Kimaro, E.L., Choong, C.-K. and Sea, L.L. (2017) 'Government Expenditure, Efficiency and Economic Growth: A Panel Analysis of Sub Saharan African Low Income Countries', African Journal of Economic Review, 05(2), 264565.

Lyatuu, I., Loss, G., Farnham, A., Winkler, M.S. and Fink, G. (2021) 'Short-term effects of national-level natural resource rents on life expectancy: A cross-country panel data analysis', PLOS ONE, 16(5), e0252336, available:

http://dx.doi.org/10.1371/journal.pone.0252336.

Ndoricimpa, A. (2017) 'Threshold Effects of Inflation on Economic Growth: Is Africa Different?', International Economic Journal, 31(4), 599-620, available: http://dx.doi.org/10.1080/10168737.2017.1380679.

Omotunde, E.G.J. (1984) 'On Growth and Inflation in Developing Countries (La croissance et l'inflation dans les pays en développement) (A propósito del crecimiento y la inflación en los países en desarrollo)', Staff Papers (International Monetary Fund), 31(4), 636660, available: http://dx.doi.org/10.2307/3866989. 
Parui, P. (2021) 'Government expenditure and economic growth: a post-Keynesian analysis', International Review of Applied Economics, 35(3-4), 597-625, available: http://dx.doi.org/10.1080/02692171.2020.1837744.

Ram, R. (1986) 'Government Size and Economic Growth: A New Framework and Some Evidence from Cross-Section and Time-Series Data', The American Economic Review, 76(1), 191-203.

Rich, R. (2013) The Great Recession, available:

https://www.federalreservehistory.org/essays/great-recession-of-200709 [accessed 27 October].

Shehata, E. and Mickaiel, S. (2015) 'RESETXT: Stata Module to Compute Panel Data REgression Specification Error Tests (RESET)'.

Tobin, J. (1972) 'Inflation and Unemployment', American Economic Review, 62(1), 1-18.

Upreti, P. (2015) 'Factors Affecting Economic Growth in Developing Countries', Major Themes in Economics, 17, 18.

World Bank (2021a) Expense (\% of GDP) [dataset].

World Bank (2021b) Inflation, consumer prices (annual \%) [dataset].

World Bank (2021c) Total natural resources rents (\% of GDP) - High income [dataset].

Wright, G. and Czelusta, J. (2011) 'Mineral Resources and Economic Development'. 


\section{Appendix}

Table 1. List of countries included in the research

\begin{tabular}{|c|c|c|}
\hline No & Code & Country \\
\hline 1 & $\mathrm{AFG}$ & Afghanistan \\
\hline 2 & DZA & Algeria \\
\hline 3 & $\mathrm{AGO}$ & Angola \\
\hline 4 & BGD & Bangladesh \\
\hline 5 & BEN & Benin \\
\hline 6 & BTN & Bhutan \\
\hline 7 & $\mathrm{BOL}$ & Bolivia \\
\hline 8 & BFA & Burkina Faso \\
\hline 9 & BDI & Burundi \\
\hline 10 & $\mathrm{CPV}$ & Cabo Verde \\
\hline 11 & KHM & Cambodia \\
\hline 12 & CMR & Cameroon \\
\hline 13 & CAF & Central African Republic \\
\hline 14 & TCD & Chad \\
\hline 15 & COD & Congo, Dem. Rep. \\
\hline 16 & $\mathrm{COG}$ & Congo, Rep. \\
\hline 17 & CIV & Côte d'Ivoire \\
\hline 18 & EGY & Egypt, Arab Rep. \\
\hline 19 & SLV & El Salvador \\
\hline 20 & SWZ & Eswatini \\
\hline 21 & ETH & Ethiopia \\
\hline 22 & GMB & Gambia, The \\
\hline 23 & GHA & Ghana \\
\hline 24 & GIN & Guinea \\
\hline 25 & GNB & Guinea-Bissau \\
\hline 26 & HTI & Haiti \\
\hline 27 & HND & Honduras \\
\hline 28 & IND & India \\
\hline 29 & $\mathrm{KEN}$ & Kenya \\
\hline 30 & KGZ & Kyrgyz Republic \\
\hline 31 & LSO & Lesotho \\
\hline
\end{tabular}

\begin{tabular}{|c|c|c|}
\hline No & Code & Country \\
\hline 32 & MDG & Madagascar \\
\hline 33 & MWI & Malawi \\
\hline 34 & MLI & Mali \\
\hline 35 & MRT & Mauritania \\
\hline 36 & MDA & Moldova \\
\hline 37 & MAR & Morocco \\
\hline 38 & $\mathrm{MOZ}$ & Mozambique \\
\hline 39 & MMR & Myanmar \\
\hline 40 & NPL & Nepal \\
\hline 41 & NIC & Nicaragua \\
\hline 42 & NER & Niger \\
\hline 43 & NGA & Nigeria \\
\hline 44 & PAK & Pakistan \\
\hline 45 & PHL & Philippines \\
\hline 46 & RWA & Rwanda \\
\hline 47 & STP & São Tomé and Principe \\
\hline 48 & SEN & Senegal \\
\hline 49 & SLE & Sierra Leone \\
\hline 50 & SLB & Solomon Islands \\
\hline 51 & SSD & South Sudan \\
\hline 52 & LKA & Sri Lanka \\
\hline 53 & TJK & Tajikistan \\
\hline 54 & TZA & Tanzania \\
\hline 55 & TGO & Togo \\
\hline 56 & TUN & Tunisia \\
\hline 57 & UGA & Uganda \\
\hline 58 & UKR & Ukraine \\
\hline 59 & VUT & Vanuatu \\
\hline 60 & VNM & Vietnam \\
\hline 61 & $\mathrm{ZMB}$ & Zambia \\
\hline 62 & ZWE & Zimbabwe \\
\hline
\end{tabular}


Table 2. Multicollinearity test results

$\begin{array}{llllll} & \text { gdpgrowth } & \text { resource } & \text { infla } & \text { exp } & \text { If } \\ \text { gdpgrowth } & 1 & & & & \\ \text { resource } & -0.1322 & 1 & & & \\ \text { infla } & -0.2515 & 0.1466 & 1 & & \\ \exp & -0.0814 & 0.1094 & 0.0171 & 1 & \\ \text { lf } & -0.1574 & 0.1982 & 0.0223 & -0.1729 & 1\end{array}$

Source: Own calculations

Table 3. Hausman test results

\begin{tabular}{|l||l|l|l||l||}
\hline & $(\mathrm{b})$ & $(\mathrm{B})$ & (b-B) & sqrt(diag(V_b \\
\hline \hline & fixed & random & Difference & Std. err. \\
\hline \hline lf & -27.2595 & -36.8918 & 9.632357 & 5.006245 \\
\hline exp & 0.083715 & -0.02554 & 0.109252 & 0.033578 \\
\hline infla & -0.23659 & -0.21751 & -0.01908 & 0.016596 \\
\hline \hline resource & 0.241223 & 0.038437 & 0.202786 & 0.032867 \\
\hline
\end{tabular}

$\mathrm{b}=$ Consistent under $\mathrm{H} 0$ and $\mathrm{Ha}$; obtained from xtreg.

$\mathrm{B}=$ Inconsistent under Ha, efficient

under $\mathrm{H}_{0} ;$ obtained from xtreg.

Test of H0: Difference in coefficients not systematic

chi2 $(4)=(b-B)^{\prime}\left[\left(V_{-} b-V \_B\right)^{\wedge}(-1)\right](b-B)$

43.81

Prob $>$ chi $2=0.0000$

Source: Own calculations

Table 4. Autocorrelation test results

Wooldridge test for autocorrelation in panel data

H0: no first-order autocorrelation

$\mathrm{F}(1, \quad 61)=1.019$

Prob $>F=0.3166$

Source: Own calculations 


\section{Table 5. Heteroskedasticity test}

Modified Wald test for groupwise heteroskedasticity in fixed effect regression model

$\mathrm{H} 0: \operatorname{sigma}(\mathrm{i})^{\wedge} 2=\operatorname{sigma}^{\wedge} 2$ for all $\mathrm{i}$

$\operatorname{chi} 2(62)=73498.00$

Prob $>$ chi $2=0.0000$

Source: Own calculations

\section{Table 6. Ramsey Reset Test results for omitted variables}

Ho: Model is Specified - Ha: Model is Misspecified

* Ramsey Specification ResetF Test

- Ramsey RESETF1 Test: $\mathrm{Y}=\mathrm{X}$ Yh2 $=68.363 \mathrm{P}$-Value

- Ramsey RESETF2 Test: $Y=X$ Yh2 Yh3 $=45.100$ P-Value

- Ramsey RESETF3 Test: Y=X Yh2 Yh3 Yh4 = 34.818 P-Value

Source: Own calculations 
Table 7. FE, RE model estimation and Hausman test results

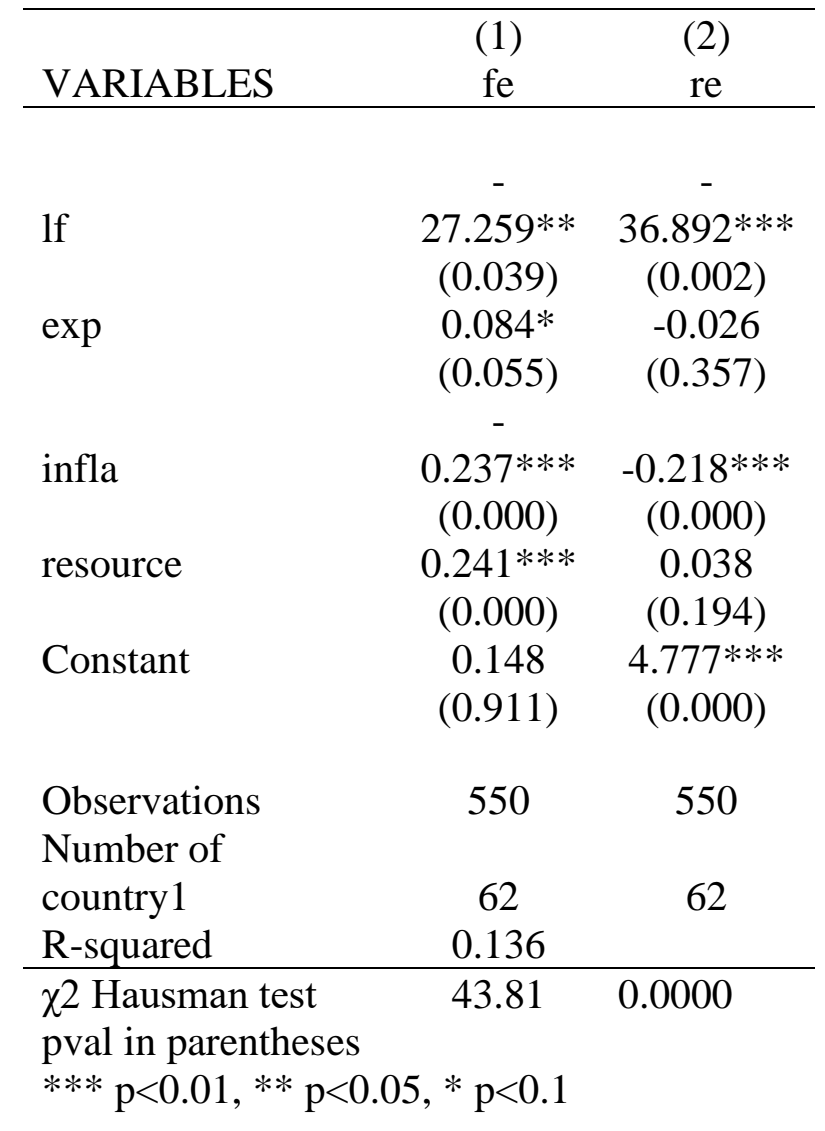

Source: Own calculations 
Table 8. FE and FE with the robust option estimations

\begin{tabular}{lcc}
\hline \multirow{2}{*}{ VARIABLES } & $(1)$ & $(2)$ \\
& $\mathrm{fe}$ & robust \\
lf & - & - \\
& $27.259 * *$ & $27.259^{* * *}$ \\
exp & $(0.039)$ & $(0.01)$ \\
& $0.084^{*}$ & $0.084^{* *}$ \\
& $(0.055)$ & $(0.019)$ \\
infla & - & \\
& $0.237 * * *$ & $-0.237 * *$ \\
resource & $(0.000)$ & $(0.016)$ \\
& $0.241^{* * *}$ & $0.241^{* * *}$ \\
Constant & $(0.000)$ & $(0.001)$ \\
& 0.148 & 0.148 \\
& $(0.911)$ & $(0.901)$ \\
Observations & 550 & 550 \\
Number of & & \\
country & 62 & 62 \\
R-squared & 0.136 & 0.136 \\
\hline \hline
\end{tabular}

Robust pval in parentheses

$* * * \mathrm{p}<0.01, * * \mathrm{p}<0.05, * \mathrm{p}<0.1$

Source: Own calculations 